\title{
Chromatographic and Spectroscopic Characterization of the Consciousness Energy Healing Treated Withania somnifera (Ashwagandha) Root Extract
}

\author{
Mahendra Kumar Trivedi ${ }^{1}$, Alice Branton ${ }^{1}$, Dahryn Trivedi ${ }^{1}$, Gopal Nayak ${ }^{1}$, \\ William Dean Plikerd ${ }^{1}$, Peter L. Surguy ${ }^{1}$, Robert John Kock ${ }^{1}$, Rolando Baptista Piedad ${ }^{1}$, \\ Russell Phillip Callas ${ }^{1}$, Sakina A. Ansari ${ }^{1}$, Sandra Lee Barrett ${ }^{1}$, Sara Friedman ${ }^{1}$, \\ Steven Lee Christie ${ }^{1}$, Su-Mei Chen Liu ${ }^{1}$, Susan Elizabeth Starling ${ }^{1}$, Susan Jones ${ }^{1}$, \\ Susan Mardis Allen ${ }^{1}$, Susanne Kathrin Wasmus ${ }^{1}$, Terry Ann Benczik ${ }^{1}$, Thomas Charles Slade ${ }^{1}$, \\ Thomas Orban ${ }^{1}$, Victoria L. Vannes ${ }^{1}$, Victoria Margot Schlosser ${ }^{1}$, Yusif Sarkis Yamin Albino ${ }^{1}$, \\ Kalyan Kumar Sethi ${ }^{2}$, Parthasarathi Panda ${ }^{2}$, Snehasis Jana ${ }^{2, *}$ \\ ${ }^{1}$ Trivedi Global, Inc., Henderson, Nevada, USA \\ ${ }^{2}$ Trivedi Science Research Laboratory Pvt. Ltd., Bhopal, India
}

Email address:

publication@trivedieffect.com (S. Jana)

${ }^{*}$ Corresponding author

To cite this article:

Mahendra Kumar Trivedi, Alice Branton, Dahryn Trivedi, Gopal Nayak, William Dean Plikerd, Peter L. Surguy, Robert John Kock, Rolando Baptista Piedad, Russell Phillip Callas, Sakina A. Ansari, Sandra Lee Barrett, Sara Friedman, Steven Lee Christie, Su-Mei Chen Liu, Susan Elizabeth Starling, Susan Jones, Susan Mardis Allen, Susanne Kathrin Wasmus, Terry Ann Benczik, Thomas Charles Slade, Thomas Orban, Victoria L. Vannes, Victoria Margot Schlosser, Yusif Sarkis Yamin Albino, Kalyan Kumar Sethi, Parthasarathi Panda, Snehasis Jana. Chromatographic and Spectroscopic Characterization of the Consciousness Energy Healing Treated Withania somnifera (Ashwagandha) Root Extract. European Journal of Biophysics. Vol. 5, No. 2, 2017, pp. 38-47. doi: 10.11648/j.ejb.20170502.12

Received: March 20, 2017; Accepted: March 31, 2017; Published: May 8, 2017

\begin{abstract}
Withania somnifera (ashwagandha) root extract is a popular health supplement, with purported health benefits including prevention and treatment of various diseases, i.e. anxiety, stress, etc. The objective of this experiment was to evaluate the impact of Energy of Consciousness Healing Treatment (The Trivedi Effect ${ }^{\circledR}$ ) on the characteristic properties of the phytoconstituents present in the ashwagandha root extract using LC-MS, GC-MS, and NMR spectroscopy. Ashwagandha root extract was divided into two parts - one part was control (without treatment), while another part was treated with the Consciousness Energy Healing Treatment remotely by twenty renowned Biofield Energy Healers and defined as the Biofield Energy Treated sample. The liquid chromatographic data of the control and Biofield Energy Treated samples revealed that the retention time of the 25 chromatographic peaks remained same, whereas the peak area $\%$ i.e. the relative amount of the phytoconstituents was altered significantly. The peak area\% of the treated ashwagandha root extract representing the phytoconstituents was significantly decreased in the range of $6.02 \%$ to $39.74 \%$ at $\mathrm{R}_{\mathrm{t}}$ of $5.2,5.3,5.4,5.6,5.7,6.9,7.1,7.3,7.8$, $7.9,8.0$, and 8.5 minutes compared to the control sample. On the contrary, the peak area\% of the other phytoconstituents present in the treated sample was significantly increased in the range of $4.12 \%$ to $82.32 \%$ at $\mathrm{R}_{\mathrm{t}}$ of $5.1,6.4,6.6,6.8,8.1,8.2$, $8.4,8.6,8.8,8.9,9.0,9.1$, and 9.2 minutes, respectively compared to the control sample. A total of 16 withanolides such as sitoindoside IX, viscosa lactone B, dihydrowithanolide D, withanolide A, withaferin A, ixocarpalactone A, withanolide sulfoxide, etc. were proposed from the molecular mass at $m / z$ 605, 489, 473, 471, 505, and 992 at the retention times of 6.9, 7.1, 7.8, 8.2, 8.5, and 9.2 minutes with the help of LC-MS, GC-MS and NMR data of both the samples. Subsequently, the mass peak intensities of the treated sample were significantly changed in the range of $-61.24 \%$ to $106.61 \%$ compared with the control sample at the same retention time. These findings suggest that Energy of Consciousness Healing Treatment could be advantageous for altering the concentration of the phytoconstituents in the ashwagandha root extract by modifying their intrinsic physicochemical properties, which might be helpful to improve the bioavailability of active constituents of ashwagandha extract that might provide better therapeutic response against inflammatory diseases, immunological disorders,
\end{abstract}


arthritis, stress, cancer, diabetes, sexual disorders, aging, and other chronic infections.

Keywords: Withania somnifera, The Trivedi Effect ${ }^{\circledR}$, Biofield Energy Healers, Energy of Consciousness Healing Treatment, Withanolides, LC-MS, GC-MS

\section{Introduction}

Withania somnifera (commonly known as ashwagandha, winter cherry, and Indian ginseng) root extract is a popular supplement, with purported health benefits including prevention and treatment of various diseases, i.e. anxiety, stress, etc. and for the good health [1-3]. It is mostly used in the herbal drugs and nutraceuticals for the treatment nervous and sexual disorders, diabetes, cancer, immunological disorders, infectious diseases, ulcer, stress, arthritis, etc. It is also used as a tonic to arrest the aging process, rejuvenate the body, and boost the defense system against infection as well as to promote the longevity of life [2-6]. The major active phytoconstituents of ashwagandha root extract are withanolides. Along with withanolides, ashwagandha root extract also contains alkaloids, sitoindosides, withanamides, reducing sugars, peroxidases, glycosides, starch, withanicil, benzyl alcohol, dilcitol, 2-phenyl ethanol, 3, 4, 5-trihydroxy cinnamic acid, benzoic acid, phenyl acetic acid, etc. [7-9]. Isolated withanolides from ashwagandha possess various pharmacological activities include antioxidant, immunomodulating, neuroprotective, hepatoprotective, antiinflammatory, hypoglycaemic, anticancer, antiarthritic, antimicrobial, etc. [10-12]. Thus, ashwagandha root extract was included as one of the constituents in a novel proprietary herbomineral formulation, which can be used for the better quality of life and prevention and treatment of various disorders.

A unique vital force preserved by every living organisms which is usually believed to create the source of life is corelated with the soul, spirit, and mind and is also recognized as prana by the Hindus, chi or $q i$ by the Chinese, and ki by the Japanese from the ancient-time. Now-a-days, this hypothetical vital force is considered as the Bioenergetics Field. This energy field is infinite, paradimensional and dynamic electromagnetic field surrounding the human body. This is also known as Biofield Energy. It can easily flow between the human and environment that leads to the continuous movement or matter of energy $[13,14]$. Thus, the human has the capability to harness energy from the earth, the "Universal Energy Field" and transmit it to any living or nonliving object (s) around the globe. The objects always receive the energy and respond in a useful way. This process is known as Biofield Energy Healing Treatment [15-17]. Biofield (Putative Energy Fields) based Energy Therapies have been practiced worldwide in different health disease profiles [18]. National Center of Complementary and Integrative Health $(\mathrm{NCCIH})$ has been recognized and accepted Biofield Energy Healing as a Complementary and Alternative Medicine (CAM) health care approach in addition to other therapies, medicines and practices such as natural products, yoga, Qi Gong, Tai Chi, deep breathing, chiropractic/osteopathic manipulation, meditation, special diets, homeopathy, progressive relaxation, massage, acupuncture, guided imagery, relaxation techniques, acupressure, hypnotherapy, movement therapy, pilates, rolfing structural integration, healing touch, Ayurvedic medicine, mindfulness, traditional Chinese herbs and medicines, essential oils, naturopathy, aromatherapy, cranial sacral therapy, Reiki, and applied prayer (as is common in all religions, like Hinduism, Buddhism, Christianity, and Judaism) [19]. The Biofield Energy Treatment (The Trivedi Effect $^{\circledR}$ ) has been extensively studied with significant outcomes in various scientific fields such as cancer research $[20,21]$, genetics [22, 23], biotechnology [24, 25], microbiology [26, 27], materials science [28-30], organic chemistry [31-33], nutraceuticals [34, 35], pharmaceuticals $[36,37]$, and agricultural science [38, 39].

Sophisticated modern instrumental techniques such as high-performance liquid chromatography (HPLC), ultraperformance liquid chromatography, normally hyphenated with mass spectrometry (MS), gas chromatography (GC), nuclear magnetic resonance (NMR) are very useful for the metabolite profiling and identification of the crude herbal extract [8, 40-42]. The LC-MS, GC-MS and NMR analysis of ashwagandha root extract revealed the presence of several known withanolides including withaferin A, withanolide D, withanoside IV/VI, withanolide sulfoxide, ixocarpalactone A, dihydrowithanolide D, etc. [43]. Therefore, LC-MS, GC-MS, and NMR analysis were conducted in this study to evaluate the effect of Energy of Consciousness Healing Treated (The Trivedi Effect $\left.{ }^{\circledR}\right)$ on the phytoconstituents of the ashwagandha root extract.

\section{Materials and Methods}

\subsection{Chemicals and Reagents}

Ashwagandha (Withania somnifera) root hydroalcoholic extract was procured from Sanat Product Ltd., India. The HPLC grade Milli Q water and acetonitrile were purchased from Millipore and Merck. All other chemicals used in the experiment were of analytical grade available in India.

\subsection{Energy of Consciousness Healing Treatment Strategies}

Ashwagandha root extract was one of the ingredients of the new proprietary herbomineral formulation, developed by our research team, and it was used per se as the test sample for the current study. The test sample was divided into two parts, one part of the test sample was treated with Consciousness Energy Healing Treatment (The Trivedi Effect $^{\circledR}$ ) by renowned Biofield Energy Healers and defined as 
Biofield Energy Treated sample, while the second part of the test sample did not receive any such treatment and defined as untreated or control ashwagandha root extract sample. The Consciousness Energy Healing Treatment was provided by the group of twenty renowned Biofield Energy Healers who participated in this study and performed the Biofield Energy Treatment (The Trivedi Effect ${ }^{\mathbb{B}}$ ) remotely. Fifteen Biofield Energy Healers were remotely located in the U.S.A., two in Canada, one in the UK, one in Australia, and one in Germany, while the test compound was located in the research laboratory of GVK Biosciences Pvt. Ltd., Hyderabad, India. This Consciousness Energy Healing Treatment was provided for 5 minutes through Healer's Unique Energy Transmission process remotely to the test compound under the laboratory conditions. None of the Biofield Energy Healers in this study visited the laboratory in person, nor had any contact with the compounds. Similarly, the control compound was subjected to "sham" healers for 5 minutes, under the same laboratory conditions. The sham healer did not have any knowledge about the Consciousness Energy Healing Treatment. The Biofield Energy Treated and untreated samples were kept in similar sealed conditions and characterized thoroughly by LC-MS, GC-MS, and NMR spectroscopy.

\subsection{Characterization}

\subsubsection{Liquid Chromatography Mass Spectrometry (LC-MS)}

The LC-MS analysis of the test samples were conducted by following the almost same method as mentioned in the recent literature [43] using The Waters ${ }^{\circledR}$ ACQUITY UPLC, Milford, MA, USA equipped with a binary pump (The Waters ${ }^{\circledR}$ BSM HPLC pump), autosampler, column heater and a photo-diode array (PDA) detector. A Triple Quad (Waters Quattro Premier XE, USA) mass spectrometer equipped with an electrospray ionization (ESI) source was used for the mass spectrometric analysis. The control and Biofield Energy Treated extract powders were dissolved in dimethyl sulfoxide to afford a $1 \mathrm{mg} / \mathrm{mL}$ stock solution. An aliquot of $2 \mu \mathrm{L}$ of the stock solution was used for LC-MS analysis with a total run time of 25 minutes. Mass spectra were recorded in the positive ionization mode and with the full scan $(\mathrm{m} / \mathrm{z} 50$ 1400).

Percent change in peak area\% $(\mathrm{T})$ was calculated using following equation (1):

$$
\% \text { change in peak area } \%=\frac{\left[\mathrm{T}_{\text {Treated }}-\mathrm{T}_{\text {Control }}\right]}{\mathrm{T}_{\text {Control }}} \times 100
$$

Where, $\mathrm{T}_{\text {Control }}$ and $\mathrm{T}_{\text {Treated }}$ are the peak area $(\%)$ of the control and Biofield Energy Treated samples, respectively.

Similarly, the percent change in mass peak intensity (I) was calculated using equation (2):

$$
\begin{aligned}
& \% \text { change in mass peak intensity } \\
& =\frac{\left[\mathrm{I}_{\text {Treated }} \mathrm{I}_{\text {Control }}\right]}{\mathrm{I}_{\text {Control }}} \times 100
\end{aligned}
$$

Where, $\mathrm{I}_{\text {Control }}$ and $\mathrm{I}_{\text {Treated }}$ are the mass peak intensity of the control and Biofield Energy Treated samples, respectively.

\subsubsection{Gas Chromatography-Mass Spectrometry (GC-MS) Analysis}

GC-MS analysis of the control and Biofield Energy Treated samples were analyzed by following the same procedure as mentioned in our recent scientific literature [43] with the help of Agilent 7890B with 5977A Mass selective detector, USA equipped with a Quadrupole detector with prefilter and flame ionization detector (FID). The control and Biofield Energy Treated ashwagandha root extract powder were dissolved in dimethyl sulfoxide to afford a $1 \mathrm{mg} / \mathrm{mL}$ stock solution. An aliquot of $1.0 \mu \mathrm{L}$ of the stock solution was injected with a total run time of $44.0 \mathrm{~min}$. The identification of analyte was performed using the retention time with a comparison of the mass spectra of the identified substances with references.

\subsubsection{Nuclear Magnetic Resonance (NMR) Spectroscopy Analysis}

${ }^{1} \mathrm{H}$ NMR and ${ }^{13} \mathrm{C}$ NMR analysis of the control and Biofield Energy Treated samples were performed on a $400 \mathrm{MHZ}$ VARIAN FT-NMR spectrometer and $100.00 \mathrm{MHz}$ on a VARIAN FT-NMR spectrometer, respectively using the same procedure as mentioned in the recent literature [43]. ${ }^{1} \mathrm{H}$ NMR multiplicities were labelled as singlet (s), doublet (d), doublet of doublet (dd), triplet (t), quartet (q), multiplet (m), broad (br), apparent (app). Chemical shifts $(\delta)$ were in parts per million (ppm) relative to the solvent's residual proton chemical shift $\left(\mathrm{CD}_{3} \mathrm{OD}, \delta=3.31,4.80 \mathrm{ppm}\right)$ and solvent's residual carbon chemical shift $\left(\mathrm{CD}_{3} \mathrm{OD}, \delta=49.15 \mathrm{ppm}\right)$.

\section{Results and Discussion}

The liquid chromatograms and the chromatographic data of the control and Consciousness Energy Healing Treated samples of ashwagandha root extract are presented in Figure 1 and Table 1, respectively. Several peaks with different retention times were observed in the LC chromatograms of the control and Biofield Energy Treated samples. Twenty five definite peaks in the chromatogram common to both the control and Biofield Energy Treated samples shown the at $\mathrm{R}_{\mathrm{t}}$ of 5.1, 5.2, 5.3, 5.4, 5.6, 5.7, 6.4, 6.6, 6.8, 6.9, 7.1, 7.3, 7.8, $7.9,8.0,8.1,8.2,8.4,8.5,8.6,8.8,8.9,9.0,9.1$, and 9.2 minutes. Along with 25 common peaks in the control and Biofield Energy Treated sample one additional peak at $\mathrm{R}_{\mathrm{t}}$ of 7.63 minutes (Figure 1) was appeared in the Biofield Energy Treated sample, which did not observed in the control sample (Figure 1). Each chromatographic peak with the corresponding $\mathrm{R}_{\mathrm{t}}$ represents one phytoconstituents present in the ashwagandha root extract. Thus, several phytoconstituents are present in the ashwagandha root extract, and the $R_{t}$ of both the control and Biofield Energy Treated samples were very close to each other (Table 1). The peak heights and areas were very important for the measurement of the relative concentration of the phytoconstituents present in the root extract. The area under the peak is directly proportional to the relative concentration 
of each compound, and these areas can be calculated [43, 44]. The peak area\% of the Biofield Energy Treated ashwagandha root extract represented the phytoconstituents were significantly decreased in the range of $6.02 \%$ to $39.74 \%$ at $\mathrm{R}_{\mathrm{t}}$ of 5.2, 5.3, 5.4, 5.6, 5.7, 6.9, 7.1, 7.3, 7.8, 7.9, 8.0, and 8.5 minutes compared to the control sample (Table 1). On the contrary, the peak area $\%$ of the other phytoconstituents present in the Biofield Energy Treated ashwagandha was significantly increased in the range of $4.12 \%$ to $82.32 \%$ at $R_{t}$ of $5.1,6.4,6.6,6.8,8.1,8.2,8.4,8.6,8.8,8.9,9.0,9.1$, and 9.2 minutes, respectively compared to the control sample (Table 1). Over all, the peak area\% of the phytoconstituents

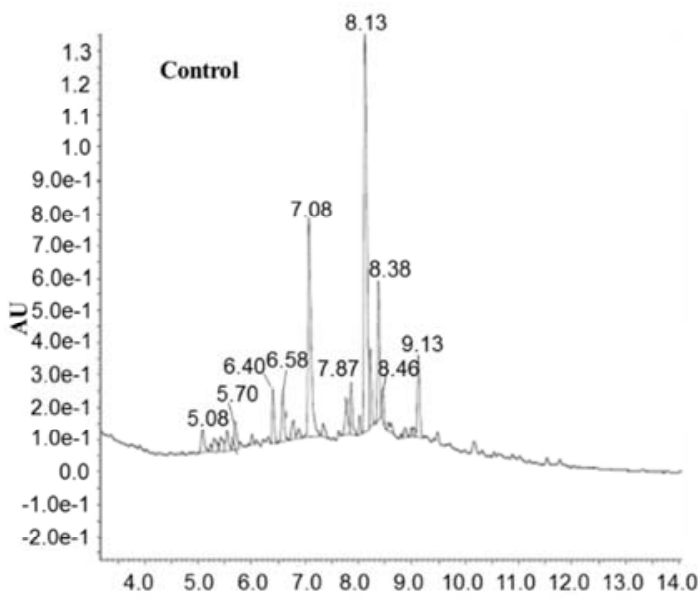

Time (min) -...-.. present in the Biofield Energy Treated ashwagandha root extract was significantly altered in the range of $-39.74 \%$ to $82.32 \%$ compared with the control sample (Table 1). It is assumed that the Consciousness Energy Healing Treatment might have the significant effect on the relative amount/concentration of the phytoconstituents present in the ashwagandha root extract. It can also be presumed that the intrinsic physicochemical properties of ashwagandha root extract, i.e. particle size, surface area, etc. that are related to the solubility of the phytoconstituents might have altered due to the Consciousness Energy Healing Treatment [28-35].

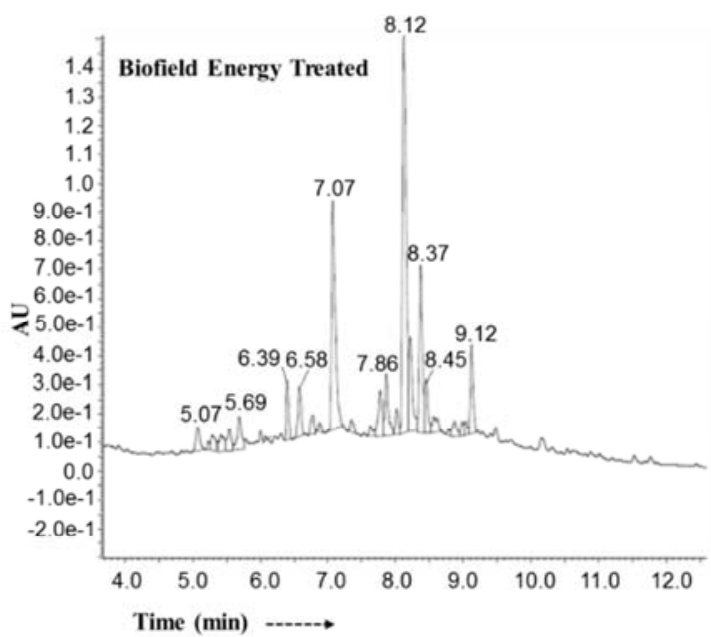

Figure 1. Liquid chromatograms of the control and Biofield Energy Treated ashwagandha root extract.

Table 1. Liquid chromatographic data of the control and Biofield Energy Treated ashwagandha root extract.

\begin{tabular}{|c|c|c|c|c|c|c|}
\hline \multirow{2}{*}{ Peak } & \multicolumn{3}{|c|}{ WS-Control } & \multicolumn{2}{|c|}{ WS-Biofield Energy Treated } & \multirow{2}{*}{$\%$ Change in PA\% ${ }^{\#}$} \\
\hline & $\mathbf{R}_{\mathbf{t}}$ & PA & $\mathbf{P A} \%$ & PA & $\mathbf{P A} \%$ & \\
\hline 1 & 5.1 & 4829.78 & 2.02 & 5642.61 & 1.77 & 14.67 \\
\hline 2 & 5.2 & 942.06 & 0.39 & 1108.30 & 0.35 & -10.26 \\
\hline 3 & 5.3 & 3192.48 & 1.33 & 3998.76 & 1.25 & -19.12 \\
\hline 4 & 5.4 & 3303.86 & 1.38 & 4602.00 & 1.44 & -12.38 \\
\hline 5 & 5.6 & 4080.16 & 1.70 & 5651.10 & 1.77 & -10.26 \\
\hline 6 & 5.7 & 5987.32 & 2.50 & 8541.15 & 2.68 & -6.02 \\
\hline 8 & 6.6 & 8671.91 & 3.62 & 9506.17 & 2.98 & 4.12 \\
\hline 9 & 6.8 & 3642.57 & 1.52 & 4001.35 & 1.25 & 7.20 \\
\hline 10 & 6.9 & 1873.54 & 0.78 & 1503.26 & 0.47 & -10.78 \\
\hline 11 & 7.1 & 45707.02 & 19.10 & 51631.00 & 16.17 & -17.68 \\
\hline 12 & 7.3 & 2560.08 & 1.07 & 2547.90 & 0.80 & -17.76 \\
\hline 13 & 7.8 & 6598.21 & 2.76 & 11152.08 & 3.49 & -39.74 \\
\hline 14 & 7.9 & 7783.58 & 3.25 & 12759.10 & 4.00 & -15.34 \\
\hline 16 & 8.1 & 76484.34 & 31.96 & 90115.46 & 28.23 & 26.45 \\
\hline 17 & 8.2 & 11068.77 & 4.63 & 20061.07 & 6.28 & 23.08 \\
\hline 18 & 8.4 & 18908.52 & 7.90 & 30104.04 & 9.43 & 37.38 \\
\hline 19 & 8.5 & 4322.44 & 1.81 & 10520.59 & 3.30 & -11.67 \\
\hline 20 & 8.6 & 2216.93 & 0.93 & 4995.72 & 1.56 & 35.64 \\
\hline 21 & 8.8 & 518.69 & 0.22 & 986.85 & 0.31 & 19.37 \\
\hline 22 & 8.9 & 1856.97 & 0.78 & 3998.57 & 1.25 & 82.32 \\
\hline 23 & 9.0 & 1021.04 & 0.43 & 2325.41 & 0.73 & 67.74 \\
\hline 24 & 9.1 & 1441.15 & 0.60 & 2495.01 & 0.78 & 40.91 \\
\hline 25 & 9.2 & 12422.98 & 5.19 & 15288.21 & 4.79 & 60.26 \\
\hline Total peak area & & 239324.54 & & $316937.28 *$ & & \\
\hline
\end{tabular}

PA: Peak Area; WS: Withania somnifera; $\mathrm{R}_{\mathrm{t}}$ : Retention time; *: includes one extra peak appeared in the TIC at $\mathrm{R}_{\mathrm{t}}$ of 7.63 minutes having peak area of 2326.07 units. "denotes the percentage change in the peak area (\%) of the Biofield Energy Treated sample with respect to the control sample. 
Table 2. Compounds proposed from ESI-MS spectra of the control and Biofield Energy Treated ashwagandha root extract.

\begin{tabular}{|c|c|c|c|c|c|}
\hline \multirow{2}{*}{$\mathbf{R}_{\mathrm{t}}(\min )$} & \multirow{2}{*}{$\operatorname{ESI-MS~}(m / z)$} & \multirow{2}{*}{ Proposed Compounds } & \multicolumn{2}{|c|}{$m / z$ peak Intensity } & \multirow{2}{*}{$\begin{array}{l}\% \text { Change } \\
\text { in Intensity }\end{array}$} \\
\hline & & & Control & Treated & \\
\hline 6.9 & $650\left[\mathrm{M}+\mathrm{NH}_{4}\right]^{+}$ & Sitoindoside IX (1) & $1.32 \mathrm{e} 6$ & $3.44 \mathrm{e} 6$ & 160.61 \\
\hline 7.1 & $\begin{array}{l}489[\mathrm{M}+\mathrm{H}]^{+} \\
506\left[\mathrm{M}+\mathrm{NH}_{4}\right]^{+}\end{array}$ & $\begin{array}{l}\beta \text {-Hydroxy-2, 3-dihydro-withanolide F (2) } \\
\text { Viscosa lactone B (3) } \\
\text { 27-Hydroxy withanolide A (4) }\end{array}$ & $1.58 \mathrm{e} 7$ & $2.55 \mathrm{e} 7$ & 61.39 \\
\hline 7.8 & $473[\mathrm{M}+\mathrm{H}]^{+}$ & $\begin{array}{l}\text { 24, 25-Dihydrowithanolide D (5) } \\
\text { 2, 3-Dihydrowithaferin A (6) }\end{array}$ & $9.49 \mathrm{e} 6$ & $1.40 \mathrm{e} 7$ & 47.52 \\
\hline & & $\begin{array}{l}\text { Withanolide A (7) } \\
\text { Withaferine A (8) } \\
\text { Withanone (9) }\end{array}$ & & & \\
\hline 8.2 & $471[\mathrm{M}+\mathrm{H}]^{+}$ & 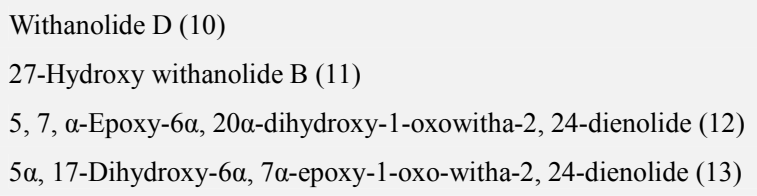 & $4.18 \mathrm{e} 7$ & $5.72 \mathrm{e} 7$ & 36.84 \\
\hline 8.5 & $505[\mathrm{M}+\mathrm{H}]^{+}$ & $\begin{array}{l}\text { Ixocarpalactone A (14) } \\
\text { Withanolide S (15) }\end{array}$ & $5.14 \mathrm{e} 6$ & $1.99 \mathrm{e} 6$ & -61.24 \\
\hline 9.2 & $992[\mathrm{M}+\mathrm{H}]^{+}$ & Withanolide sulfoxide (16) & $2.47 \mathrm{e} 6$ & $1.66 \mathrm{e} 6$ & -32.79 \\
\hline
\end{tabular}

$\mathrm{R}_{\mathrm{t}}$ : retention time; $m / z$ : mass-to-charge ratio; ${ }^{*}$ denotes the percentage change of the Biofield Energy Treated sample with respect to the control sample.

Among these 25 chromatographic peaks, only six peaks at $\mathrm{R}_{\mathrm{t}}$ of $6.9,7.1,7.8,8.2,8.5$, and 9.2 minutes having significant peak area\% responded to the mass spectrometer and afforded the respective ESI-MS spectra (Table 2). With the help of ESI-MS, GC-MS, NMR spectral data, and our recent literature [43] sixteen withanolides are proposed from the control and Biofield Energy Treated samples (Table $2 \&$ Figure 2). The chromatographic peak at $R_{t}$ of 6.9 minutes reflect the ammonium adduct ion peak in the mass spectra at $m / z 650\left[\mathrm{M}+\mathrm{NH}_{4}\right]^{+}$(calcd for $\mathrm{C}_{34} \mathrm{H}_{52} \mathrm{NO}_{11}, 650$ ) along with lower mass peak at $\mathrm{m} / z 471$ proposed to be sitoindoside IX (1) (Figure 2) in the control and Biofield Energy Treated samples. The peak area $\%$ of sitoindoside IX (1) was decreased by $10.78 \%$, and the mass peak intensity at $\mathrm{m} / z 650$ was significantly increased by $160.61 \%$ in the Biofield Energy Treated sample compared with the control sample (Tables 2). Similarly, at $\mathrm{R}_{\mathrm{t}}$ of 7.1 minutes, $3 \beta$-hydroxy-2, 3dihydro-withanolide $\mathrm{F}$ (2) or viscosa lactone $\mathrm{B}$ (3) or 27hydroxy withanolide $\mathrm{A}(4)$ were proposed with molecular ion peak at $m / z 489[\mathrm{M}+\mathrm{H}]^{+}$(calculated for $\mathrm{C}_{28} \mathrm{H}_{40} \mathrm{O}_{7}$, 489) and ammonium adduct ion peak at $m / z 650\left[\mathrm{M}+\mathrm{NH}_{4}\right]^{+}$in the mass spectra of the control and Biofield Energy Treated sample (Table $2 \&$ Figure 2). The peak area $\%$ was decreased by $17.68 \%$, but the mass peak intensity at $\mathrm{m} / \mathrm{z} 489$ was decreased by $61.39 \%$ in the Biofield Energy Treated sample compared with the control sample (Tables $1 \& 2$ ).

24, 25-dihydrowithanolide D (5) or 2, 3-dihydrowithaferin A (6) were proposed [43] with molecular ion peak at $\mathrm{m} / \mathrm{z} 473$ (calculated for $\mathrm{C}_{28} \mathrm{H}_{40} \mathrm{O}_{6}, 473$ ) at $\mathrm{R}_{\mathrm{t}}$ of 7.8 minutes (Table 2 $\&$ Figure 2). The peak area\% was significantly decreased by $39.78 \%$, but the mass peak intensity at $\mathrm{m} / z \quad 473$ was significantly increased by $47.52 \%$ in the Biofield Energy
Treated sample compared with the control sample (Tables 1 $\&$ 2). With the help of the spectral data and our recent literature [43], withanolide A (7) or withaferin A (8) or withanone (9) or withanolide D (10) or 27-hydroxy withanolide $\mathrm{B}(11)$ or $5,7, \alpha$-epoxy- $6 \alpha, 20 \alpha$-dihydroxy-1-

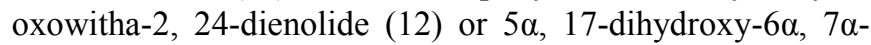
epoxy-1-oxo-witha-2, 24-dienolide (13) (Table $2 \&$ Figure 2) were proposed with the molecular ion peak of $m / z 471$ [M + $\mathrm{H}]^{+}$(calcd for $\mathrm{C}_{28} \mathrm{H}_{39} \mathrm{O}_{6}, 471$ ) in the mass spectra of both the samples $\left(\mathrm{R}_{\mathrm{t}}\right.$ of 8.2 minutes). The GC-MS and NMR data (Figures $3 \& 4$ respectively) also supported the presence of any of the compounds $7-13$. The peak area $\%$ and mass peak intensity at $\mathrm{m} / \mathrm{z} 471$ were significantly increased by $23.08 \%$ and $36.84 \%$, respectively in the Biofield Energy Treated sample compared with the control sample (Tables $1 \& 2$ ). Ixocarpalactone A (14) or withanolide $\mathrm{S}$ (15) were proposed with $\mathrm{m} / \mathrm{z} 505[\mathrm{M}+\mathrm{H}]^{+}$(calculated for $\mathrm{C}_{28} \mathrm{H}_{40} \mathrm{O}_{8}, 505 ; \mathrm{R}_{\mathrm{t}}$ of 8.5 minutes) (Table $2 \&$ Figure 2). The peak area\% and the peak intensity at $\mathrm{m} / \mathrm{z} 505$ of this compound 14 or 15 were significantly decreased by $11.67 \%$ and $61.24 \%$, respectively in the Biofield Energy Treated sample compared with the control sample (Tables 1 \& 2). Ixocarpalactone A (14) was reported to be promising anti-tumor agent [43, 45]. The withanolide proposed for the chromatographic peak at $\mathrm{R}_{\mathrm{t}}$ of 9.2 minutes and $\mathrm{m} / \mathrm{z} 992[\mathrm{M}+\mathrm{H}]^{+}$(calculated for $\mathrm{C}_{56} \mathrm{H}_{79} \mathrm{O}_{13} \mathrm{~S}$, 992) in the mass spectra was withanolide sulfoxide (16) (Table $2 \&$ Figure 2). The change in peak area $\%$ of withanolide sulfoxide (16) was significantly increased by $60.26 \%$, but mass peak intensity at $\mathrm{m} / \mathrm{z} 992$ was significantly decreased by $32.79 \%$ in the Biofield Energy Treated sample compared with the control sample (Tables 1 \& 2). 


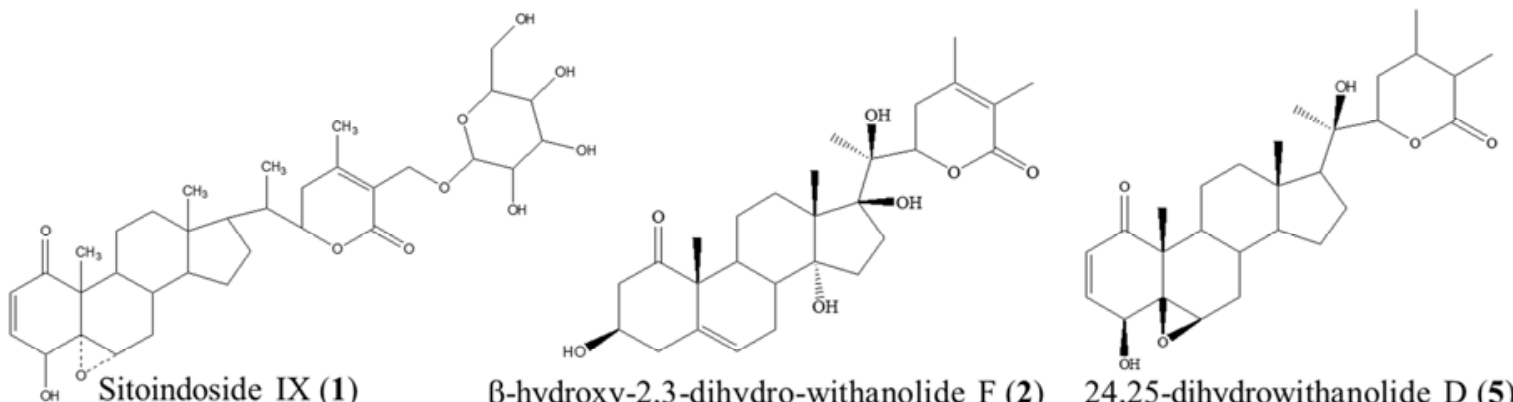

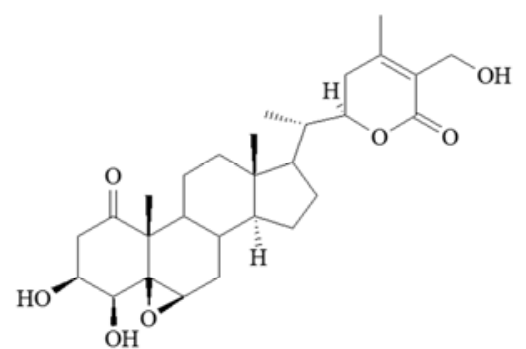

Visco salactone B (3)

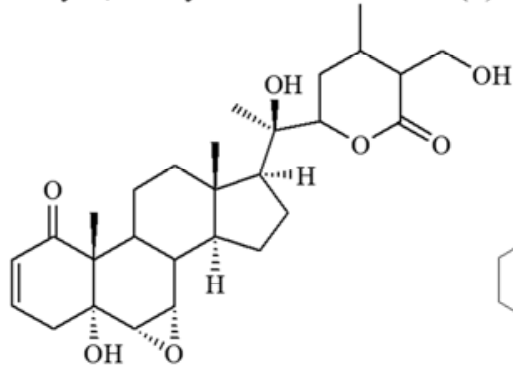

27-Hydroxy withanolide A (4)

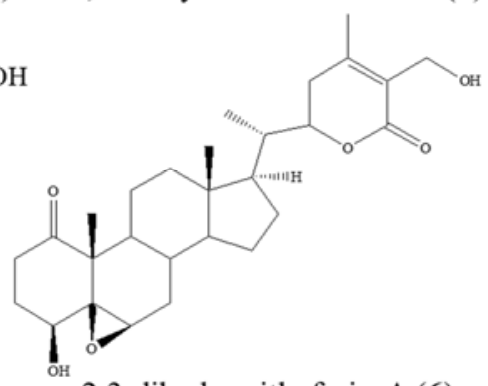

2,3-dihydrowithaferin A (6)

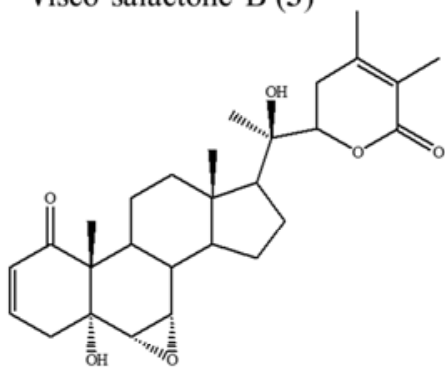

Withanolide A (7)<smiles></smiles>

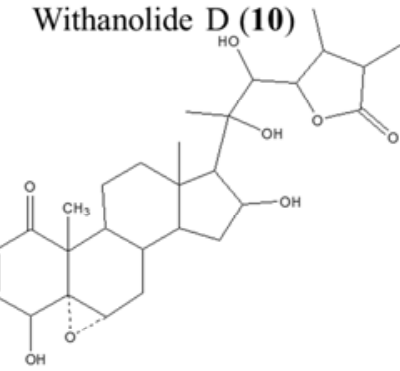

Ixocarpalactone A (14)

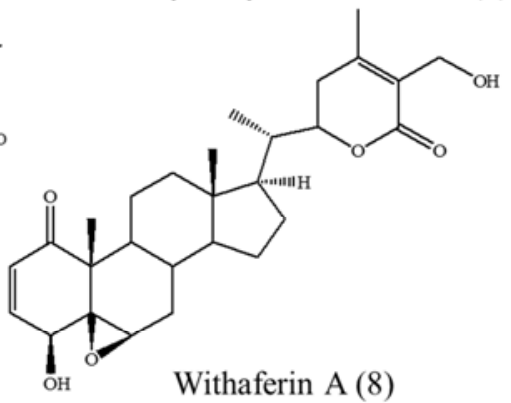

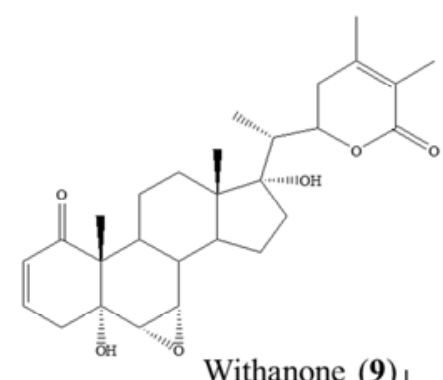

Withaferin A (8)

Withanone (9)

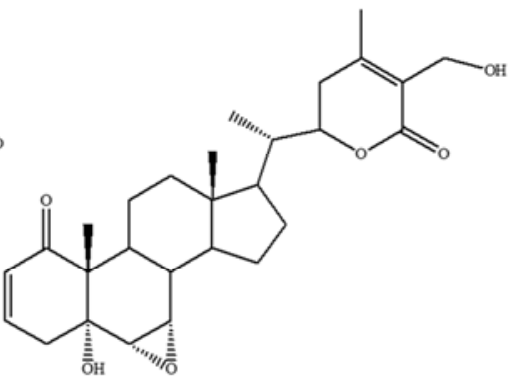

27-Hydroxy withanolide B (11)

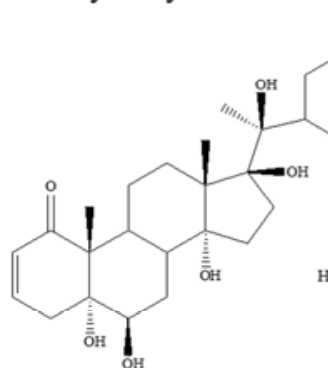

Withanolide S (15)

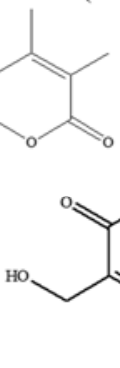

Withanolide sulfoxide (16)

Figure 2. Structures of the proposed compounds.

The mass spectroscopic data revealed that the mass fragmentation pattern of the control and Biofield Energy Treated samples were almost similar pattern. But, the mass peak intensities of the Biofield Energy Treated sample were significantly altered in the range of $-61.24 \%$ to $106.61 \%$ compared to the control sample with respect to the same retention time. This finding suggested that the natural isotopic abundance ratio of the identified phytoconstituents in the ashwagandha root extract might be altered due to the Consciousness Energy Healing Treatment. 

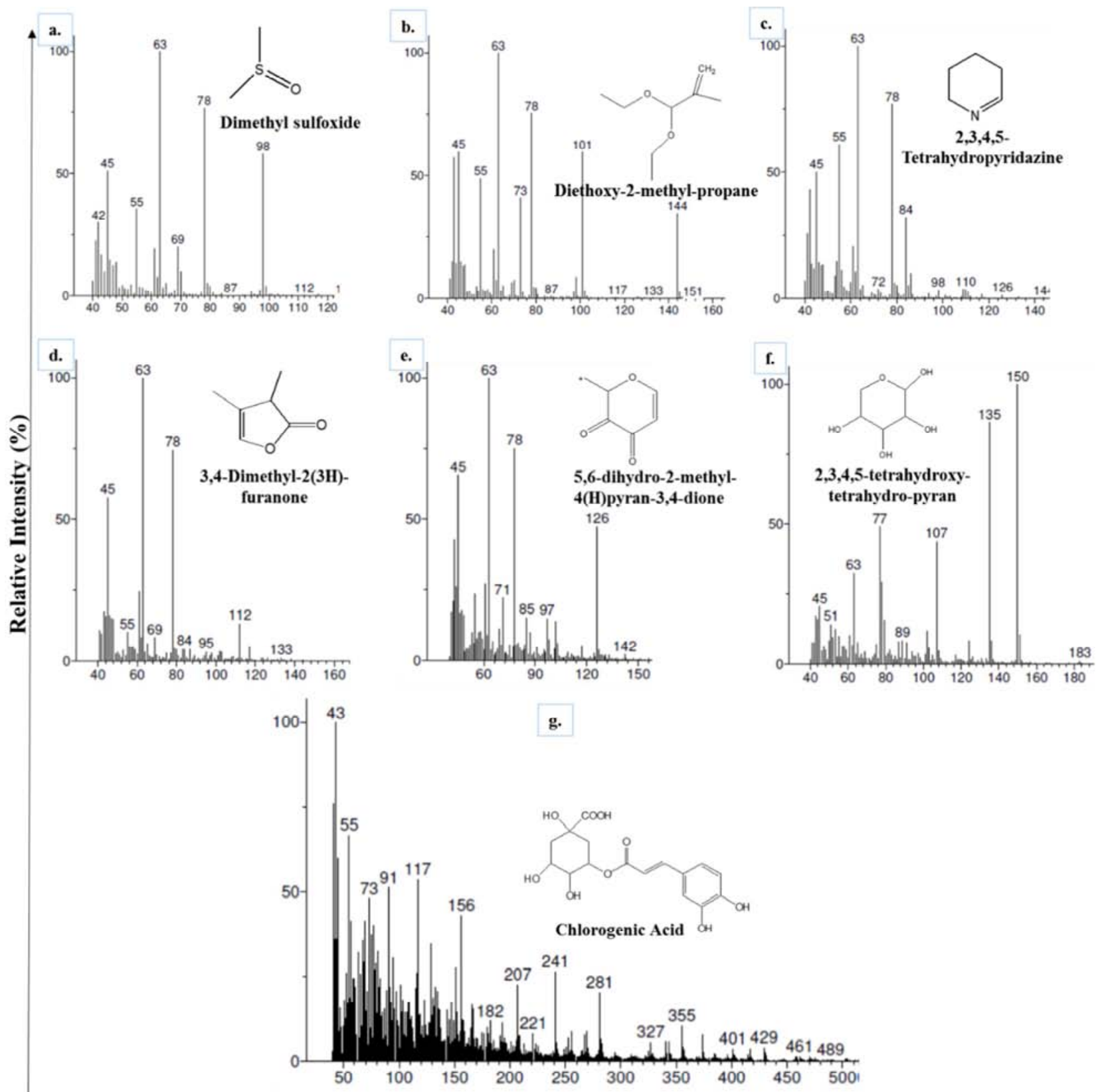

$m / z$

Figure 3. GC-MS spectra of the ashwagandha root extract with the proposed fragmentation of compounds.

Control

(a)

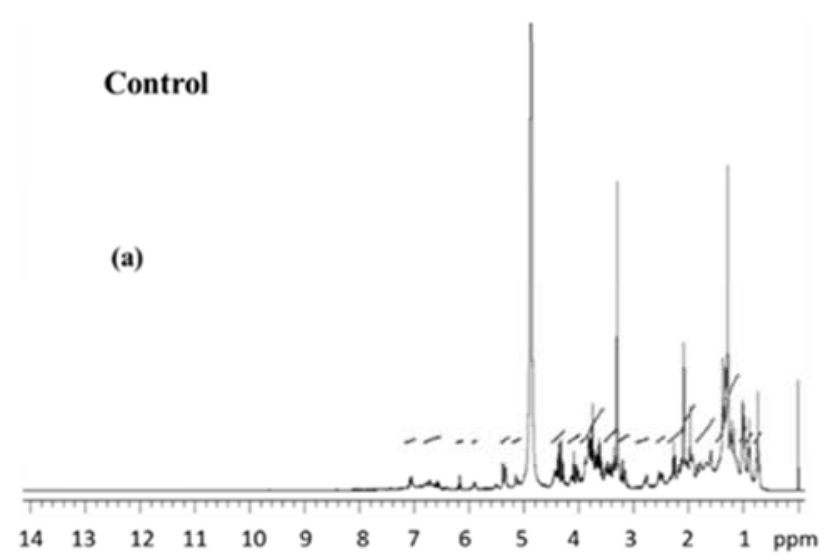

Biofield Energy Treated

(b)

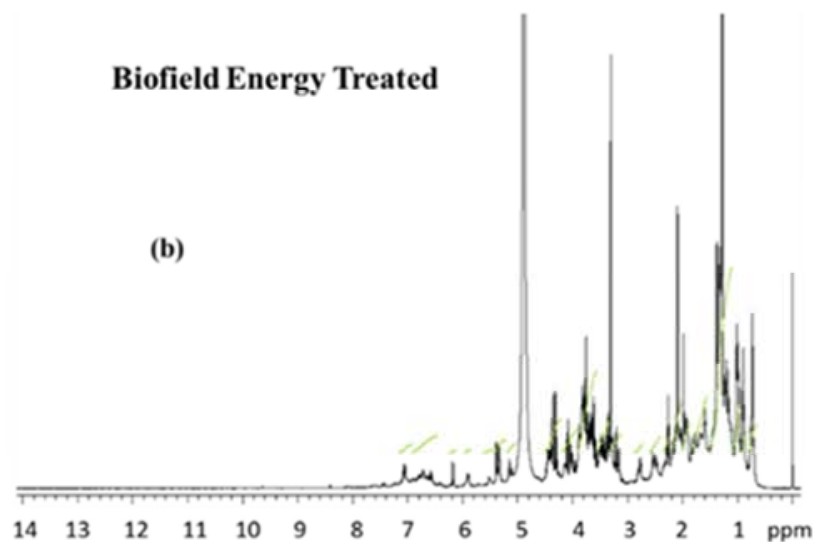


(c)

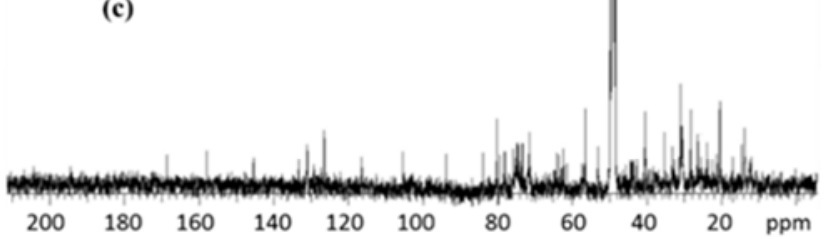

(d)

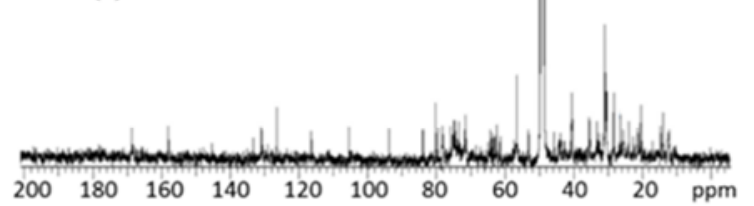

Figure 4. ${ }^{1} \mathrm{H}$ NMR spectra of the control (a), Biofield Energy Treated (b); ${ }^{13} \mathrm{C} N M R$ spectra of the control (c), and Biofield Energy Treated (d) ashwagandha root extract.

\section{Conclusions}

The chromatographic and spectroscopic characterization of ashwagandha root extract concluded that Energy of Consciousness Healing Treatment (The Trivedi Effect ${ }^{\mathbb{R}}$ ) has the significant effect on the peak area\% (i.e. the relative concentration of the phytoconstituents) and mass peak intensities. The liquid chromatographic data of the control and Biofield Energy Treated samples revealed that the retention time of the 25 chromatographic peaks remained same, whereas the peak area $\%$ i.e. the relative amount of the phytoconstituents was significantly altered in the Biofield Energy Treated sample from $-39.74 \%$ to $82.32 \%$ compared to the control sample. A total of 16 withanolides such as sitoindoside IX, viscosa lactone $\mathrm{B}$, dihydrowithanolide $\mathrm{D}$, withanolide $\mathrm{A}$, withaferin $\mathrm{A}$, ixocarpalactone $\mathrm{A}$, withanolide sulfoxide, etc. were proposed from the molecular mass at $\mathrm{m} / \mathrm{z}$ $605,489,473,471,505$, and 992 at retention times of $6.9,7.1$, $7.8,8.2,8.5$, and 9.2 minutes with the help of LC-MS, GC-MS and NMR data of both the samples. Subsequently, the mass peak intensities of the Biofield Energy Treated sample were significantly changed in the range of $-61.24 \%$ to $106.61 \%$ compared with the control sample at the same retention time. The Energy of Consciousness Healing Treatment could be valuable for altering the concentration of the phytoconstituents in the ashwagandha root extract by modifying their intrinsic physicochemical properties, which might be helpful to improve the bioavailability of its phytoconstituents. Thus, Biofield Energy Treated ashwagandha root extract might provide better therapeutic response against various diseases such as diabetes mellitus, septic shock, and allergies; stressrelated disorders like sleep disorder, depression, anxiety, insomnia, low libido, brain frog, mental restlessness (mind chattering), impotency, lack of motivation, fear of the future, confusion, migraines, forgetfulness, loneliness, headaches, irritability, worthlessness, indecisiveness, chronic fatigue, frustration, and panic attacks; inflammatory diseases and immunological disorders like Lupus, Hashimoto Thyroiditis, Type 1 Diabetes, Chronic peptic ulcers, Tuberculosis, Asthma, Chronic active hepatitis, Hepatitis, Graves' Disease, Addison Disease, Pernicious and Sjogren Syndrome, Crohn's disease, Aplastic Anemia, Multiple Sclerosis, Rheumatoid arthritis, Chronic periodontitis, Ulcerative colitis, Myasthenia Gravis,
Chronic sinusitis, Atherosclerosis, Dermatitis, Diverticulitis, Rheumatoid Arthritis, Reactive Arthritis, Fibromyalgia, Scleroderma, Chronic Fatigue Syndrome, Psoriasis, agingrelated diseases like cardiovascular disease, cancer, Alzheimer's disease, diabetes, dementia, cataracts, osteoporosis, hypertension, Parkinson's Disease, hearing loss, Prion Disease, Amyotrophic lateral sclerosis, Motor Neuron Disease, Spinocerebellar Ataxia, Spinal muscular atrophy, chronic infections and much more.

\section{Abbreviations}

DMSO: Dimethyl sulfoxide, EI: Electron ionization, ESI: Electrospray ionization, LC-MS: Liquid chromatography-mass spectrometry, PDA: Photodiode array, $\mathrm{R}_{\mathrm{t}}$ : Retention time, UPLC: Ultra-performance liquid chromatography, GC-MS: Gas chromatography-mass spectrometry, $m / z$ : Mass-to-charge ratio, NMR: Nuclear magnetic resonance spectroscopy.

\section{Acknowledgements}

The authors are grateful to GVK Biosciences Pvt. Ltd., Trivedi Science, Trivedi Global, Inc. and Trivedi Master Wellness for their assistance and support during this work.

\section{References}

[1] Kesarwani K, Gupta R (2013) Bioavailability enhancers of herbal origin: An overview. Asian Pac J Trop Biomed 3: 253-266.

[2] Singh N, Bhalla M, Jager P, Gilca M (2011) An overview on ashwagandha: A rasayana (rejuvenator) of Ayurveda. Afr J Tradit Complement Altern Med 8: 208-213.

[3] Kulkarni SK, Dhir A (2008) Withania somnifera: An Indian ginseng. Prog Neuropsychopharmacol Biol Psychiatry 32: 1093-1105.

[4] Dar NJ, Hamid A, Ahmad M (2015) Pharmacologic overview of Withania somnifera, the Indian ginseng. Cell Mol Life Sci 72: 4445-4460.

[5] Mir BA, Khazir J, Mir NA, Hasan T-ul, Koul S (2012) Botanical, chemical and pharmacological review of Withania somnifera (Indian ginseng): An Ayurvedic medicinal plant. Indian J Drugs Dis 1: 147-160. 
[6] Mishra LC, Singh BB, Dagenais S (2000) Scientific basis for the therapeutic use of Withania somnifera (Ashwagandha): A review. Altern Med Rev 5: 334-346.

[7] Kumar V, Dey A, Hadimani MB, Marcović T, Emerald M (2015) Chemistry and pharmacology of Withania somnifera: An update. Tang (Humanitas Medicine) 5: e1.

[8] Bolleddula J, Fitch W, Vareed SK, Nair MG (2012) Identification of metabolites in Withania sominfera fruits by liquid chromatography and high-resolution mass spectrometry. Rapid Commun Mass Spectrom 26: 1277-1290.

[9] Mirjalili MH, Moyano E, Bonfill M, Cusido RM, Palazón J (2009) Steroidal lactones from Withania somnifera, an ancient plant for novel medicine. Molecules 14: 2373-2393.

[10] Singh A, Duggal S, Singh H, Singh J, Katekhaye S (2010) Withanolides: Phytoconstituents with significant pharmacological activities. Int J Green Pharm 4: 229-237.

[11] Chen LX, He H, Qiu F (2011) Natural withanolides: An overview. Nat Prod Rep 28: 705-740.

[12] Budhiraja RD, Krishan P, Sudhir S (2000) Biological activity of withanolides. J Sci Ind Res 59: 904-911.

[13] Stenger VJ (1999) Bioenergetic fields. Sci Rev Alternative Med 3.

[14] Rogers, M (1989) "Nursing: A Science of Unitary Human Beings." In J. P. Riehl-Sisca (ed.) Conceptual Models for Nursing Practice. 3rd edition. Norwark: Appleton \& Lange.

[15] Rosa L, Rosa E, Sarner L, Barrett S (1998) A close look at therapeutic touch. JAMA 279: 1005-1010.

[16] Warber SL, Cornelio D, Straughn, J, Kile G (2004) Biofield energy healing from the inside. J Altern Complement Med 10: 1107-1113.

[17] Nelson LA, Schwartz GE (2005) Human biofield and intention detection: Individual differences. J Altern Complement Med 11: 93-101.

[18] Nemeth L (2008) Energy and biofield therapies in practice. Beginnings. Summer 28: 4-5.

[19] Koithan M (2009) Introducing complementary and alternative therapies. J Nurse Pract 5: 18-20.

[20] Trivedi MK, Patil S, Shettigar H, Mondal SC, Jana S (2015) The potential impact of biofield treatment on human brain tumor cells: A time-lapse video microscopy. J Integr Oncol 4: 141.

[21] Trivedi MK, Patil S, Shettigar H, Gangwar M, Jana S (2015) In vitro evaluation of biofield treatment on cancer biomarkers involved in endometrial and prostate cancer cell lines. J Cancer Sci Ther 7: 253-257.

[22] Trivedi MK, Branton A, Trivedi D, Nayak G, Mondal SC, Jana S (2015) Evaluation of antibiogram, genotype and phylogenetic analysis of biofield treated Nocardia otitidis. Biol Syst Open Access 4: 143.

[23] Trivedi MK, Branton A, Trivedi D, Nayak G, Gangwar M, Jana S (2015) Antibiogram, biochemical reactions, and genotypic pattern of biofield treated Pseudomonas aeruginosa. J Trop Dis 4: 181.

[24] Trivedi MK, Branton A, Trivedi D, Nayak G, Gangwar M,
Jana S (2015) Bacterial identification using 16S rDNA gene sequencing and antibiogram analysis on biofield treated Pseudomonas fluorescens. Clin Med Biochemistry Open Access 1: 101.

[25] Trivedi MK, Patil S, Shettigar H, Gangwar M, Jana S (2015) In vitro evaluation of biofield treatment on cancer biomarkers involved in endometrial and prostate cancer cell lines. J Cancer Sci Ther 7: 253-257.

[26] Trivedi MK, Branton A, Trivedi D, Nayak G, Mondal SC, Jana S (2015) Antimicrobial sensitivity, biochemical characteristics and biotyping of Staphylococcus saprophyticus: An impact of biofield energy treatment. J Women's Health Care 4: 271.

[27] Trivedi MK, Patil S, Shettigar H, Gangwar M, Jana S (2015) Effect of biofield treatment on antimicrobials susceptibility pattern of Acinetobacter baumannii - An experimental study. J Clin Diagn Res 3: 1 .

[28] Trivedi MK, Patil S, Tallapragada RM (2013) Effect of biofield treatment on the physical and thermal characteristics of vanadium pentoxide powders. J Material Sci Eng S 11: 001.

[29] Trivedi MK, Tallapragada RM, Branton A, Trivedi D, Nayak G, Latiyal O, Jana S (2015) Characterization of physical and structural properties of aluminum carbide powder: Impact of biofield treatment. J Aeronaut Aerospace Eng 4: 142.

[30] Trivedi MK, Tallapragada RM, Branton A, Trivedi D, Nayak G, Latiyal O, Jana S (2015) The potential impact of biofield energy treatment on the atomic and physical properties of antimony tin oxide nanopowder. American Journal of Optics and Photonics 3: 123-128.

[31] Trivedi MK, Branton A, Trivedi D, Nayak G, Panda P, Jana S (2016) Gas chromatography-mass spectrometric analysis of isotopic abundance of ${ }^{13} \mathrm{C},{ }^{2} \mathrm{H}$, and ${ }^{18} \mathrm{O}$ in biofield energy treated $p$-tertiary butylphenol (PTBP). American Journal of Chemical Engineering 4: 78-86.

[32] Trivedi MK, Branton A, Trivedi D, Nayak G, Sethi KK, Jana S (2016) Gas chromatography-mass spectrometry based isotopic abundance ratio analysis of biofield energy treated methyl-2-napthylether (Nerolin). American Journal of Physical Chemistry 5: 80-86.

[33] Trivedi MK, Branton A, Trivedi D, Nayak G, Bairwa K, Jana $\mathrm{S}$ (2015) Spectroscopic characterization of disodium hydrogen orthophosphate and sodium nitrate after biofield treatment. J Chromatogr Sep Tech 6: 282.

[34] Trivedi MK, Tallapragada RM, Branton A, Trivedi D, Nayak G, Latiyal O, Jana S (2015) Potential impact of biofield treatment on atomic and physical characteristics of magnesium. Vitam Miner 3: 129.

[35] Trivedi MK, Tallapragada RM, Branton A, Trivedi D, Nayak G, Mishra RK, Jana S (2015) Biofield treatment: A potential strategy for modification of physical and thermal properties of gluten hydrolysate and ipomoea macroelements. J Nutr Food Sci 5: 414.

[36] Trivedi MK, Patil S, Shettigar H, Bairwa K, Jana S (2015) Effect of biofield treatment on spectral properties of paracetamol and piroxicam. Chem Sci J 6: 98.

[37] Trivedi MK, Patil S, Shettigar H, Singh R, Jana S (2015) An impact of biofield treatment on spectroscopic characterization of pharmaceutical compounds. Mod Chem Appl 3: 159. 
[38] Trivedi MK, Branton A, Trivedi D, Nayak G, Gangwar M, Jana S (2015) Agronomic characteristics, growth analysis, and yield response of biofield treated mustard, cowpea, horse gram, and groundnuts. International Journal of Genetics and Genomics. 3: 74-80.

[39] Trivedi MK, Branton A, Trivedi D, Nayak G, Mondal SC, Jana S (2015) Evaluation of plant growth, yield and yield attributes of biofield energy treated mustard (brassica juncea) and chick pea (Cicer arietinum) seeds. Agriculture, Forestry and Fisheries. 4: 291-295.

[40] Chatterjee S, Srivastava S, Khalid A, Singh N, Sangwan RS, Sidhu OP, Roy R, Khetrapal CL, Tuli R (2010) Comprehensive metabolic fingerprinting of Withania somnifera leaf and root extracts. Phytochemistry 71: 10851094.

[41] Chaurasiya ND, Uniyal GC, Lal P, Misra L, Sangwan NS, Tuli R, Sangwan RS (2008) Analysis of withanolides in root and leaf of Withania somnifera by HPLC with photodiode array and evaporative light scattering detection. Phytochem Anal 19: 148-154.
[42] Musharraf SG, Ali A, Ali RA, Yousuf S, Rahman AU, Choudhary MI (2011) Analysis and development of structurefragmentation relationships in withanolides using an electrospray ionization quadropole time-of-flight tandem mass spectrometry hybrid instrument. Rapid Commun Mass Spectrom 25: 104-114.

[43] Trivedi MK, Panda P, Sethi KK, Jana S (2017) Metabolite profiling of Withania somnifera roots hydroalcoholic extract using LC-MS, GC-MS and NMR spectroscopy. Chem Biodivers 14: e1600280.

[44] https://www.scribd.com/document/220440935/Theory-ofHPLC-Quantitative-and-Qualitative-HPLC.

[45] Mulabagal V, Subbaraju GV, Rao CV, Sivaramakrishna C, Dewitt DL, Holmes D, Sung B, Aggarwal BB, Tsay HS, Nair MG (2009) Withanolide sulfoxide from Aswagandha roots inhibits nuclear transcription factor- $\mathrm{\kappa B}$, cyclooxygenase and tumor cell proliferation. Phytother Res 23: 987-992. 